\title{
A Study of Companies' Strategy for Securing Appropriability: Focused on South Korean Electronic Component Manufacturing
}

\author{
Kwan-Woo Cheon', Young-Ki Kim², Soo-Myung Choi ${ }^{2}$ and Seong-Taek Park ${ }^{2 *}$ \\ 'Videojet Techonologies Inc, Korea; kwanu1004@naver.com \\ 2Department of Management Information Systems, Chungbuk National University, Korea; ykkim@cbnu.ac.kr, \\ kb508@hanmail.net, solpherd@cbnu.ac.kr
}

\begin{abstract}
Objectives: This study is intended to deal with appropriability in electronic components of Korea, aimed to study measures for strategies to secure revenue in terms of R\&D. Methods/Statistical Analysis: The study is based on the Delphi methodology in a rank format. Thus, this study was performed divided into three stages as shown in Schmidt et al. The first was a brainstorming step. The second was reducing a step of reducing the entry of the list. The third was a step of ranking factors. Based on this, priorities of appropriability were determined. Findings: These studies conducted a Delphi survey of the factors presented in the preceding research with experts and primarily draw five factors of the method for securing profitability from R\&D. This study analyzed the importance of five appropriability factors with electronic component manufacturers through a ranking-type Delphi method. As a result, the order of importance was as follows: Patent, complementary sales/service, secret, lead-time advantage and complementary manufacturing. Application/ Improvements: The field experts' opinions were reflected, and with the results of this survey, proper interpretations can be drawn and used by making use of their experiences in the field.
\end{abstract}

Keywords: Appropriability, Complementary, Lead Time Advantage, Patent, Trade Secret

\section{Introduction}

In the 21st century, with informatization, liberalization and globalization, the competition gradually deepens, and companies take a lot of pain to change uncertain management environments. Entering the period of global competition, it has become very difficult for companies to survive unless they thoroughly prepare. In addition, with sudden changes to limitless competition and knowledge informatization society, the level of consumers' demands and stakeholders' requirements increase, so the situations are changing in which the survival is no longer possible only with a competitive advantage of the past. Accordingly, in order to adapt themselves to a new environment, it seems that companies will finally be placed in a situation of a decline unless they create a new competitive advantage with continuous change and innovative effort. For instance, in the smartphone market, there are very serious changes. Considered absolute strong, Nokia and Motorola have already fallen behind since they did not make new innovations in the smartphone market, and Sony, which had been strong in the electronics industry, too, does not enjoy the past glories in the market. In contrast, Korean Samsung Electronics and Chinese Huawei made good use of innovation to join the rank of success ${ }^{1}$.

Since $^{2}$ started studying company's innovation activities, studies of technical innovation have continuously been conducted till now. In particular, advanced countries and global companies are accelerating their transition to the knowledge-based economy through studies of basic science and efforts for $\mathrm{R} \& \mathrm{D}^{\underline{3}}$. In addition, in recent years, with the convergence of science and technology, new products or services have been emerging, and companies have formed continuous networks with suppliers,

${ }^{*}$ Author for correspondence 
customers, and competitors and accelerated technical innovation through them ${ }^{4}$.

Companies do not always succeed in spite of their investment in R\&D. Even though they developed a technology through $\mathrm{R} \& \mathrm{D}$, the technology becomes useless unless they commercialize or industrialize it. Thus, it is very important to find a measure to achieve a high ratio of efficiency to investment in $\mathrm{R} \& \mathrm{D}$. This is called appropriability in other words. Appropriability refers to the degree of an ability to protect and secure profits exclusively for technical innovation, and representatively, there are appropriability mechanisms such as patent, trade secret, lead-time, complementary sales/service, and complementary manufacturing $\stackrel{1}{\text {. }}$.

However, since each researcher defines factors of appropriability differently, this study examined preceding research and referred to experts' opinions to draw the factors of appropriability. In addition, this study attempted to examine what factors the domestic electronic component manufacturers used in making innovations. This study conducted a survey of the strategy for securing appropriability with practitioners of the electronic component manufacturers and analyzed the research results through a comparison with the preceding research.

\section{Theoretical Backgrounds}

This study would define appropriability as the degree of an ability to protect and secure profits from technical innovation exclusively and that of an ability to secure profits from investment in $R \& D^{3,5}$.

\subsection{Patent}

A patent is a monopolistic, exclusive right granted to the highly advanced creation of technical idea using natural law by a state, which is granted to a highly advanced invention, in other words, a great invention (Korean Intellectual Property Office). In general, the right to claim is given exclusively for 20 years from the date of the patent application. This refers to securing profits with the right given to an inventor if the inventor first invented a product or a method which had not existed through technical innovation $\frac{3-6}{}$.

\subsection{Trade Secret (Secrecy)}

The information inside a company is not known to the outside world publicly. In addition, it refers to information with an independent economic value and technological or managerial information useful for the company's activities, such as a production method kept secret by considerable effort or manufacturing secret. Such a corporate secret can be protected for unlimited period unless leaked out, unlike a patent. It refers to recognizing its property value and protecting and securing profits while technical innovation is maintained and managed as a secret.

\subsection{Lead-time Advantage}

Lead-time refers to shortening the time taken till the release of a product, and it can be said to be preoccupancy in the market. When a company enters a new industry or market, it has great risks. And yet, if it preoccupies the market with lead-time, it is difficult for a competitor and potential entering company to enter the market it has preoccupied. Especially, lead-time can be a very useful strategy since for a technology with a relatively shorter life, preoccupying the market by releasing a product in the market acts more advantageous rather than maintaining a patent or secret $\frac{3-6}{}$.

\subsection{Complementary Saales/Service}

This refers to securing profits, making use of promoting the use value of a product by employing an additional product/service through technical innovation.

It can increase sales of a product, brand value, and product value because of the improvement of the company's image. In addition, the company uses it in order to complement the existing sales or service through $\mathrm{R} \& \mathrm{D}$ for the supplementation of manufacturing and service in the market.

\subsection{Complementary Manufacturing}

This refers to enhancing the manufacturing capacity and reducing the manufacturing process through technical innovation and securing profits through a complementary role that can reduce product cost through the improvement of product quality.

\subsection{Preceeding Research}

$\operatorname{In}^{\mathrm{z}}$ investigated patents, trade secret, and the economy of scale, costs for the imitation of competitors, know-how and brand awareness with 130 companies. In $^{8}$ presented patents, confidentiality, preoccupancy in the market, and the supplementation of merchandising and service. 
$\mathrm{In}^{9}$ studied Switzerland companies by presenting to a patent to prevent replicas, a patent for royalties, trade secret, lead-time, and efforts for merchandising and service.

In ${ }^{10}$ presented five factors, including patent, trade secret, lead-time, complementary sales/service and complementary manufacturing with 1,478 American manufacturers.

$\mathrm{In}^{\frac{5}{5}}$ conducted an empirical analysis of appropriability to secure profits for $\mathrm{R} \& \mathrm{D}$ in the domestic mobile phone industry. $\mathrm{In}^{3}$ performed an analysis of the preference for the strategy to secure appropriability with experts in the Korean software industry.

$\operatorname{In}^{6}$ drew 13 appropriability mechanisms to analyze the differences and types of the mechanisms for securing compensation of technical innovation and conducted an empirical analysis with experts in companies.

$\mathrm{In}{ }^{11}$ conducted an empirical analysis of the importance of eight appropriability factors with experts of seven industries and found that there were differences in the appropriability mechanism according to the industry.

\section{Research Design and Investugation Method}

Generally, methodologies to draw priority include a scoring method, ranking-type Delphi method, paired comparison method and AHP method, and this study will determine the priority through the ranking-type Delphi method in order to draw and analyze the priority of appropriability mechanisms.

\subsection{Data Collection and Analysis Method}

$\mathrm{In}^{\underline{12}}$ it was conducted by three stages. First, in the brainstorming stage, many factors are extracted. Second, it is a stage in which the items in the list are reduced ${ }^{12}$. In the third stage, the ranking of the selected factors is determined. In other words, the panels determine the ranking of the factors on the list made in the second stage in the order of importance.

\subsection{Operational Definition}

Table 1 shows operational definition.

\subsection{Characteristics of Sample}

This study conducted a survey of executives in electronic component manufacturers, and the characteristics of the samples of the six final respondents are as follows. Of the entire samples, the positions of the respondents were senior researchers, associate researchers or staff researchers. All of them had a work experience more than five years, and most of them had a level of education, a master's or doctoral degree or higher. The company to which the respondents belong are companies with excellent capabilities, such as Companies L., R., D. and B. of South Korea.

Table 1. Operational definition

\begin{tabular}{|l|l|}
\hline Patent & $\begin{array}{l}\text { The right to claim is given exclusively } \\
\text { for } 20 \text { years from the date of the patent } \\
\text { application }\end{array}$ \\
\hline $\begin{array}{l}\text { Trade Secret } \\
\text { (Secrecy) }\end{array}$ & $\begin{array}{l}\text { The information inside a company is } \\
\text { not known to the outside world publicly }\end{array}$ \\
\hline $\begin{array}{l}\text { Lead-time } \\
\text { Advantage }\end{array}$ & $\begin{array}{l}\text { Shortening the time taken till the } \\
\text { release of a product, and it can be said } \\
\text { to be preoccupancy in the market }\end{array}$ \\
\hline $\begin{array}{l}\text { Complementary } \\
\text { Saales/Service }\end{array}$ & $\begin{array}{l}\text { Securing profits, making use of } \\
\text { promoting the use value of a product } \\
\text { by employing an additional product/ } \\
\text { service through technical innovation }\end{array}$ \\
\hline $\begin{array}{l}\text { Complementary } \\
\text { Manufacturing }\end{array}$ & $\begin{array}{l}\text { Enhancing the manufacturing capacity } \\
\text { and reducing the manufacturing } \\
\text { process through technical innovation } \\
\text { and securing profits }\end{array}$ \\
\hline
\end{tabular}

\section{Results of Analysis}

\subsection{Priority of Appropriability}

Table 2 is the result of analysis of the priority of appropriability factors.

Table 2. Priority of appropriability factors

\begin{tabular}{|l|l|l|l|l|l|l|l|l|l|}
\hline & $\mathrm{A}$ & $\mathrm{B}$ & $\mathrm{C}$ & $\mathrm{D}$ & $\mathrm{E}$ & $\mathrm{F}$ & Average & VAR & SD. \\
\hline Patent & 1 & 1 & 1 & 1 & 1 & 1 & 1.00 & 0.00 & 0.00 \\
\hline Secret & 3 & 2 & 4 & 2 & 3 & 3 & 2.83 & 0.57 & 0.75 \\
\hline Lead time Advantage & 4 & 3 & 3 & 4 & 4 & 4 & 3.67 & 0.27 & 0.52 \\
\hline Complementary Sales/Service & 5 & 5 & 5 & 5 & 5 & 5 & 5.00 & 0.00 & 0.00 \\
\hline Complementary Manufacturing & 2 & 4 & 2 & 3 & 2 & 2 & 2.50 & 0.70 & 0.84 \\
\hline
\end{tabular}


The result of the analysis of the priority is as follows: Patent (1.00), Complementary Manufacturing (2.50) and Secret (2.83). The reason why the above result was drawn seems to be caused by the characteristics of the electronic component industry. In the electronic component industry, there are many rival companies, globally, and there is a high tendency to obtain monopolistic, exclusive rights by applying for patents as there are increasing cases in which companies holding a source technology dominate the market.

For example, Qualcomm has the source patent for CDMA that currently South Korea uses as the communication standard and receives a royalty, and it is known that its royalty income accounts for over $40 \%$ of the entire sales. To that extent, a patent is the most powerful method of securing profits.

Complementary manufacturing ranked second. No matter how up-to-date technology, it cannot secure profits unless there is a manufacturing capacity (complementary manufacturing), the base of manufacturing and commercialization.

For example, the importance of complementary manufacturing can also be noted in the case of Samsung Electronics and Apple Inc. currently in patent disputes. Apple Inc. released iPhone (Generation 1) and created a smartphone fever globally.

So, Samsung Electronics began to launch Androidbased smartphones to compete with iPhone. Samsung Electronics early smartphone (Galaxy S) was not a product as innovative as Apple iPhone, but based on its manufacturing capacity, it slowly began to encroach on the smartphone market, and as of 2015, it has the world's first market share for smartphones, followed by Apple Inc.

On the background of this success, various factors are working, but Samsung's strength is that it has the capability to adjust output at any time as it pleases. In the meantime, most rival companies outsource. Outsourcing is one of the trends frequently used by global manufacturers since it has many advantages. However, Samsung Electronics is different in that it uses insourcing, instead of outsourcing. Complementary manufacturing of competitive products is one of the best methods with an ability to dominate the market based on the perfect understanding of the competitor's manufacturing capacity and products, overcome the disadvantages as a late mover and secure appropriability through this ${ }^{3}$.

Secret ranked third. In general, companies attach importance to patent, but they usually protect important information as know-how. This is because even that information that has a potential of exhibiting an economic value in the future (potentially useful information), even if a trade secret is not actually used, and information like research data that failed in the past may have an economic value (KIPO).

Usually, trade secret seems to be unimportant in electronic component manufacturing, but it is not true. Of course, it ranked third, lower than a patent, but failed data or technologies that have not been commercialized yet can be protected as secrets and utilized in the future.

Lead-time ranked fourth. As the competition becomes more intense in the market, a company with a capability which preoccupies the market can enjoy various advantages. Apple Inc., for example, released iPod and iPhone, etc. in the market faster than other rival companies and earns huge profits from its markets throughout the world. In addition, by the nature of an electronics manufacturer, it has many competitors and product life cycle itself is shorter than that of other industrial sectors, so this result was caused by high recognition of the priority of the importance of lead-time.

Complementary sales/service ranked fifth. Complementary sales/service is as important as other appropriabilities. This is because no profits can be secured even with a product with a good technology without complementary sales/service (Supplementation). In $\underline{13}$ argued that securing complementary assets would be a means for existing operators to increase bargaining power.

Samsung Electronics, which entered the smartphone market as a late mover did not release more innovative products as compared to Apple Inc. did, but overcame its disadvantage as a late mover through occupying the distribution channels $s^{3}$.

\subsection{Comparison with Preseding Research}

This study aims to draw important factors of appropriability of domestic electronic component manufacturers, so examined the differences from preceding research in Table 3.

First, the biggest difference is the patent selected as the most important factors in this study. $\mathrm{In}^{10}$ complementary manufacturing was selected as the most important factor in the electronic component industry. The target companies in this survey are electronic component manufacturers, so it seems that patent application is judged to be the most important factor of the factors of appro- 
priability. However, in another domestic study conducted by $^{1}$, a secret was selected as the most important factor.

Table 3. Comparison with preseding research

\begin{tabular}{|l|l|l|l|l|l|}
\hline & factor & This Study & In $^{10}$ & In $^{1}$ & In $^{3}$ \\
\hline 1 & Patent & 1 & 5 & 1 & 2 \\
\hline 2 & Secret & 3 & 4 & 4 & 1 \\
\hline 3 & $\begin{array}{l}\text { Lead time } \\
\text { Advantage }\end{array}$ & 4 & 3 & 2 & 3 \\
\hline 4 & $\begin{array}{l}\text { Complementary } \\
\text { Sales/Service }\end{array}$ & 5 & 2 & 3 & 4 \\
\hline 5 & $\begin{array}{l}\text { Complementary } \\
\text { Manufacturing }\end{array}$ & 2 & 1 & 4 & 5 \\
\hline
\end{tabular}

In the U.S., for the past 30 years, there has been a strong tendency to protect patents ${ }^{10}$. Due to the strong protection of patents, successful evaluations have been made, and the number of patents, too, increased greatly. And yet, the steep growth of patents, the cumulative character of innovation and the combination of each ownership formed a patent thicket that deters efforts for the commercialization of useful technologies. Accordingly, in patent ranked fifth $\underline{5}$.

Complementary sales/service ranked second. They ranked fifth in this study. However, in ${ }^{10}$ they ranked second and third in 1 .

The reason for these results is that, in the Korean market environment, generally, patent and trade secret are preferred as strategies for appropriability. Korea has relatively lacking basic and source technologies, so the focus is always brought to the use of technologies of advanced countries. Accordingly, the reason is that it tends to put a lower priority to complementary sales/service as a measure for investing in $\mathrm{R} \& \mathrm{D}$ and securing profits, compared to other factors.

Confidentiality ranked third. It ranked third in this study. However, ${ }^{10}$ it ranked fourth based on the entire industries, and in ${ }^{1}$, it ranked first. It is judged that the reason is that, for the industries in the U.S., confidentiality is preferred, following preoccupancy in the market as a result of R\&D. For example, Coca-Cola did not apply for a patent. If Coca-Cola applied the secrets of manufacturing the crude liquid as a patent, there might be no Coca-Cola like now.

To that extent, for the company, the patent application is important, but it is judged that there is a tendency to secure competitiveness by keeping it a secret of the company rather than patent application. It seems that there is a difference since the software industry was the subject of the survey in 1 . Of course, software, too, is now protected legally, but still, there is a high tendency to protect it as a trade secret rather than as an intellectual property right.

Lastly, these differences are caused by the differences in the subjects of the survey. In ${ }^{110}$ conducted a survey with 1,478 R\&D institutes for 33 industries in the U.S. In ${ }^{1}$ limited the subjects of the survey to Korean cell phone parts companies, and ${ }^{3}$, too, conducted a survey only with the software of the Korean IT industrial sectors.

This study conducted a survey on a certain industry, so there was a difference in priority from the preceding research. In addition,,$^{10}$ used average; by ${ }^{11}$, pair wise comparison; and ${ }^{3}$, AHP method; however, this study drew priority, using a weighted value through the ranking-type Delphi method, and thus, this result came out.

\section{Conclusions}

This study conducted a Delphi survey of the factors presented in the preceding research with experts and primarily draw five factors of the method for securing profitability from R\&D. With the five factors drawn, such as patent, complementary sales/service, secret, lead-time advantage and complementary manufacturing, the priority was analyzed through a weighted value through a ranking-type Delphi method. As a result of an analysis, in the cell phone parts industry, the importance turned out to be in the following order: Patent, complementary manufacturing and trade secret.

As strategies for securing appropriability in the electronic component industry, it turned out that two strategies, patent application, and complementary manufacturing to secure a source technology are most important.

The operational implications of this study are as follows. First, five factors selected by six practitioners help establish an appropriability assurance method model in a company, and it seems that they can be applied to practice by modifying and supplementing the evaluation criteria and evaluation alternatives. Second, using the ranking-type Delphi method, the field experts' opinions were reflected, and with the results of this survey, proper interpretations can be drawn and used by making use of their experiences in the field.

Limitations of this study and the future research direction are as follows: In the methodology of priority, more importance is attached to the expertise of respon- 
dents than to the number of respondents. However, this study does not have various subjects, so it has a limitation in terms of the breadth of analysis. In addition, unlike the preceding research, a survey analysis was conducted, centering around a certain industry, and it was based on a limited number of respondents, so it would be difficult to generalize the results of this study.

In the future study, regarding the method of securing appropriability, it would be necessary to diversify the industrial sectors, expand the subjects of the survey, and investigate the differences in the methods of securing appropriability according to each industrial sector and product group.

\section{References}

1. Park ST, Lee SJ, Kim YK. Establishing the importance weight of patent valuation criteria for product categories through AHP analysis. Entrue Journal of Information Technology. 2011 Jan; 10(1):115-27.

2. Schumpeter JA. Capitalism, socialism and democracy. George Allen and Unwin: London; 1976.

3. Lee SJ, Park ST, Kim YK. Appropriability mechanism strategy for domestic IT manufacturing companies. Journal of Digital Convergence. 2013 Nov; 11(11):233-42.

4. Yoo BK. R\&D investment and economic result. Science and Technology Policy. 2004; 146:1-20.

5. Park ST, Lee SJ, Jung SH, Kim YK. A study on the secure plan of profit in R\&D: Centering on centering on cellu- lar phone parts industry. Humanities and Social Science Studies. 2010 Aug; 28:139-62.

6. Park ST, Kim YK. Difference across indutries of innovation appropriability mechanism's effectiveness and classification. Journal of Digital Convergence. 2014 Jun; 12(6):135-44.

7. Wyatt S, Bertin G, Pavitt K. Patents and multinational corporations : results from questionnaires. Wolrd Patent Information. 1985 Dec; 7(3):196-212.

8. Levin RC, Klevorick AK, Nelson RR, Winter SG. Appropriating the returns from industrial research and development. Brookings Papers on Economic Activity. 1987; 18(3):783-820.

9. Harabi N. Appropriability of technical innovations an empirical analysis. Research Policy. 1995 Nov; 24(6):98192.

10. Cohen WM, Nelson RR, Walsh JP. Protecting Their intellectual assets: appropriability conditions and why U.S. manufacturing firms patent(or Not). Working Paper. No. 7552. National Bureau of Economic Research; 2000.

11. Park ST, Lee SJ, Kim YK. Appropriability of innovation results: case of the korean industry. Indian Journal of Science and Technology. 2015 Sep; 8(21):1-6.

12. Schmidt RC, Lyytinen K, Keil M, Cule P. Identifying software project risk: an international delphi study. Journal of Management Information Systems. 2001; 17(4):5-36.

13. Gans JS, Stern S. The product market and the market for ideas : Commercialization strategies for technology entrepreneurs. Research Policy. 2003 Feb; 32(2):333-50. 